\title{
From De-Humanization to the Flourishing Feast: A Study of Ecological Conversion by means of a Triple Colloquy with Pope Francis, Pope John Paul II, and Bernard Lonergan, S.J.
}

\author{
Christopher Krall, S.J. \\ Marquette University (Milwaukee, WI)
}

In Laudato Si, Pope Francis calls for an 'ecological conversion' by entrusting humanity with the responsibility of stewardship as protectors and preservers of a nature projected toward divinization in the eternal heavenly feast (\#236). However, it was Pope John Paul II who first utilized the term in his 2001 General Audience (Wednesday, 17 Jan. 2001) while contemplating Psalm 148's delightful imagery of the marvels of creation. JPII announced, "We must therefore encourage and support the 'ecological conversion' which in recent decades has made humanity more sensitive to the catastrophe to which it has been heading. [The human person] is no longer the Creator's 'steward', but an autonomous despot who is finally beginning to understand that [they] must stop at the edge of the abyss" (GA\#4). The saint elaborated his description of the abyss as devastation and "unrestrained industrialization" of the "flowerbed" - to use an image from Dante Alighieri (Paradiso, XXII, 151) - which is the earth, our dwelling-place" (GA \#3). The feast for all of our senses, our windows to the soul, ${ }^{1}$ that nature provides, is lost to us as we become blind, deaf, numb, and oblivious to the groanings of creation (see Romans 8:22) due to the dominating role that we assume over nature. The need for an awakening or conversion has only magnified over the last twenty years since JPII was urging for a "rediscovered harmony with nature

\footnotetext{
${ }^{1}$ See William Blake, “The Everlasting Gospel” \#170-175.
} 
and with one another" (\#5). Pope Francis addresses this issue head on in Laudato Si pressing the world's population to embrace a stance of stewardship, rather than dominance, for our common home. The grace-induced awakening from living as autonomous despots to becoming selftranscendent, self-giving, and compassionate stewards of our home and all of creation allows for a cosmic communitarian feast and is conversion in an ecological key.

Ecological conversion consists of a profound awakening and radical change. JPII emphasized how this change consists of a two-fold movement of, first, the preservation of safeguarding the habitat of all living beings, and second, the development of a "human ecology" or "human environment" that upholds the moral structure of dignity in which each person has been endowed. He addressed the critical balance between nature as manifested in each living species with that of the sanctity of the human person. ${ }^{2}$ The ultimate fulfilment toward which conversion leads is what JPII described in his final encyclical, Ecclesia de Eucharistia. Partaking in the feast of the Eucharist is humanity's telos as it "unites heaven and earth. It embraces and permeates all creation. The Son of God became [human] in order to restore all creation... He, the Eternal High Priest, who by the blood of his Cross entered the eternal sanctuary, thus gives back to the Creator and Father all creation redeemed" ( $E d E \# 8)$. The feast at which heaven and earth unite is the great vision of redemption.

Francis advances JPII's two-fold thrust by stressing how "everything is interconnected, and that genuine care for our own lives and our relationships with nature is inseparable from fraternity, justice, and faithfulness to others" ( $L S \# 70)$. How we treat each other as persons mimics how we treat nature and vice-versa. Francis urges humanity to recognize the harmonious

\footnotetext{
${ }^{2}$ Such a balance is then elaborated in John Paul II, Man and Woman He Created Them: A Theology of the Body, trans. Michael Waldstein (Boston: Pauline Books and Media, 2006); And his earlier work Karol Wojtyla, Love and Responsibility, trans. H.T. Willetts (New York: Farrar, Straus, Giroux, 1981).
} 
relationships amid all of creation and roots ecological conversion, which awakens with in an encounter with Jesus Christ, in the cosmic feast of the Eucharist. Francis writes, "it is in the Eucharist that all that has been created finds its greatest exaltation. Grace, which tends to manifest itself tangibly, found unsurpassable expression when God [...] became [human] and gave [God's self] as food for [all] creatures" ( $L S \# 236)$. Participation in the heavenly feast of the Eucharist is a participation in God's grace which is the force that unifies creation back to God. The ecological conversion for which both JPII and Francis call is a turning ${ }^{3}$ of the human soul away from prideful, selfish, anthropocentric tendencies and toward Jesus Christ, through whom all of creation was made and who continually invites humanity into the heavenly feast.

Does ecological conversion fit, however, with deeper traditional understandings of conversion, and, if it does, what nuanced distinctions does it add? To address these questions, I turn to Bernard Lonergan, a twentieth-century theologian rooted in the work of Thomas Aquinas who identified the study of conversion as the fundamental work of theology. In Method in Theology, Lonergan explained that conversion, "is a resultant change of course and direction. It is as if one's eyes were opened and one's former world faded and fell away. There emerges something new that fructifies in inter-locking, cumulative sequences of developments on all levels and in all departments of human living." Conversion, he explained, is personal in how it "affects a [person's] conscious and intentional operations; it directs [the] gaze, pervades [the] imagination, releases the symbols that penetrate to the depths of [the] psyche, it enriches [the] understanding, guides [the] judgements, reinforces [the] decisions." ${ }^{5}$ Conversion, he wrote, is the foundation of

\footnotetext{
${ }^{3}$ Turning ( $\sigma \tau \rho \varepsilon ́ \varphi \omega /$ strephō), is a key term used in Christian theology of conversion. See Emilie Griffin, Turning: Reflections on the Experience of Conversion (New York: Doubleday, 1980). See also John 20:11-18 "Mary turned..."

${ }^{4}$ Bernard J.F. Lonergan, Method in Theology (Toronto: University of Toronto Press, 1990), 130.

${ }^{5}$ Lonergan, Method in Theology, 131.
} 
the reflection on religion, which is distinct from but integrally linked with theology: "for religion is conversion in its preparation, in its occurrence, in its development, in its consequents, and also alas in its incompleteness, its failures, its breakdowns, its disintegration. Now theology, and especially the empirical theology of today, is reflection on religion." ${ }^{6}$ Conversion, according to Lonergan, is an ongoing, dynamic expansion of one's consciousness because of the inflow of divine grace that becomes a living religion spreading to communities, cultures, and future generations. $^{7}$

Most foundationally, Lonergan underscored that authentic religious conversion is becoming part of the Body of Christ through grace. ${ }^{8}$ This movement into Christ culminates at the feast of authentic knowing at the table of wisdom and authentic living through self-appropriation. The best and most authentic self is one who is more and more consciously a living member of Christ Jesus' Body. This vision of fulfilment is supported by "The First Principle and Foundation" as outlined by St. Ignatius Loyola in the Spiritual Exercises and it corresponds with the sacred living temple St. Paul described as "the dwelling place of God in the Spirit" (Ep 2:19-22). This radical change, Lonergan stressed, is God pouring God's tangible and efficacious grace into our

\footnotetext{
${ }^{6}$ Bernard J.F. Lonergan, "Theology in its New Context," in Renewal of Religious Thought: Proceedings of the Congress on the Theology of the Renewal of the Church Centenary of Canada, 1867-1967, ed. L.K. Shook, C.S.B. (Montreal: Palm Publishers, 1986), 45.

${ }^{7}$ Lonergan discussed three specific types of conversion and Robert Doran added a fourth which coincides with the five levels of the general empirical method of knowing. For a full description of this see Robert M. Doran, Theology and the Dialectics of History (Toronto, University of Toronto Press, 1990), 59: "Religious conversion, the process of falling in love with God, and the dynamic state of being in love with God, affects proximately a dimension of consciousness-at times Lonergan called it a fifth level- where we are pure openness to the reception of grace; moral conversion affects the fourth level; intellectual conversion affects the second and third levels; and psychic conversion affections the first level."

${ }^{8}$ See Bernard J.F. Lonergan, "Grace and the Spiritual Exercises of St. Ignatius," Method: Journal of Lonergan Studies, 21, no. 2 (2003), 90-91: "Grace is that by which (i) we are (ii) more and more we are (iii) living members of Christ Jesus and (iv) more and more fully and [ever] more consciously living members of Christ Jesus. Grace is that by which, that which makes it really true, that we, the whole of us, body and soul, biologically, sensitively, intellectually, voluntarily, are living members of Christ Jesus." The process, and most often a long process, of authentic human growth entails a change from existence as an individual sinner to living as a beloved member of the body of Christ.
} 
hearts (Rom 5:5) so as to awaken us to a glimpse of the heavenly feast in the light of glory. ${ }^{9}$ To support the fact that humanity was created by God with the telos as the beatific feast of heaven, Lonergan sets up the syllogism of faith. He wrote, "whatever God knows and truthfully reveals to humankind is to be believed by us; and if that which is to be believed exceeds the natural proportion of the human intellect, then we are in fact ordered and destined to a supernatural end."10 Lonergan's concept of the religious conversion is the recognition of the fact that what God has revealed to humanity does indeed exceed the human intellect. The supernatural end for which humanity and all of creation is ordered is the great feast of the heavenly banquet overflowing with God's love and grace.

Intellectual conversion, which is integral to Lonergan's notion of religious conversion, frees a person from distorted knowing and acting caused by bias. A limited consciousness or stubbornly narrow worldview starves a person from the truth as it is the basis of egoism, the cause of communal blindness, and the trigger of sinful self-centered perspectives. The basic definition of bias is "a flight from understanding [which] blocks the occurrence of the insights that would upset its comfortable equilibrium."11 Bias stunts learning first in one person, then it spreads like a virus to infect communities, cultures, and swaths of the population. Lonergan described the longer cycle of decline by using the analogy of the wheel of progress that is clogged by distorting effects of bias. And yet, through divine grace and the process of conversion, the will is re-oriented

\footnotetext{
${ }^{9}$ For a comprehensive description of Aquinas's and Lonergan's Trinitarian Theology see Robert M. Doran, The Trinity in History: A Theology of the Divine Missions: Volume Two: Missions, Relations, and Persons (Toronto: University of Toronto Press, 2019) "what Thomas and Lonergan call the light of glory is the created condition of the 'vision,' that is, the immediate knowledge of God that we already hope for in this life as we yearn to 'see' the Father."

${ }^{10}$ Bernard J.F. Lonergan, “Analysis of Faith,” Method: Journal of Lonergan Studies 20, no. 2 (2002), 125-154, 126.

${ }^{11}$ Bernard J.F. Lonergan, Insight: A Study of Human Understanding, Collected Works of Bernard Lonergan, Volume 3, eds. Frederick E. Crowe and Robert M. Doran (Toronto: University of Toronto Press, 2000), 6. Lonergan named four ways bias can be manifest: dramatic, individual, group, and general bias.
} 
and flooded with aspirations toward the heavenly feast for which humanity was originally ordered. $^{12}$

In establishing authentic religious conversion as turning from sinful and restrictive perspectives, does the living Body of Christ, which is freed from bias, include the environment? According to Pauline ecclesiology, arguably not. Persons form the living Church with Christ as head $(\mathrm{Col} 1: 18)$. Lonergan rarely refers to nature as he sees nature as a contrast to direct revelation and through which humanity can experience a mediated limited knowledge of God, as "through a glass darkly."13 However, JPII stressed the Body of Christ lives and moves and has being within the "human environment" or Francis names "our common home" (LS\#1). The unified community encompasses human society, the social order, the family as the sanctuary of life, and nature, which contains the visible messages of the invisible God in goodness, truth, and beauty (see JPII, Centesimus Annus, \#37-39). Ecological conversion is possible precisely through the wisdom God reveals through nature. With the grace manifested in ecological conversion, God's infinite beauty becomes more visible and, as Francis writes, "eternal life will be a shared experience of awe, in which each creature, resplendently transfigured, will take its rightful place...[in] the heavenly feast" (LS \#243-244).

If ecological conversion is an authentic conversion, it necessarily requires an expansion of human consciousness, reversing the cycle of decline into dehumanization. Both JPII and Francis are well aware of the disastrous effects of sinful human actions. JPII warned of, "the problem of consumerism... [which is the] desire to have and to enjoy rather than to be and to grow." He addressed "an anthropological error [which is when humanity] discovers [its] capacity to transform

\footnotetext{
12 See Lonergan, "Grace and the Spiritual Exercises of St. Ignatius," 91.

${ }^{13}$ See Bernard J.F. Lonergan, "Natural Knowledge of God," in A Second Collection: Collected Works of Bernard Lonergan, Volume 13, eds. Robert Doran, S.J., John Dadosky (Toronto: University of Toronto Press, 2016), 101.
} 
and in a certain sense create the world through [its] own work, but forgets that this is always based on God's prior and original gift of the things that are." JPII described "the poverty or narrowness of [a person's] outlook, motivated as [the person] is by a desire to possess things rather than relate them to the truth" (JPII, CA, \#37-39). Likewise, Francis, with no lack of clarity, writes of the social ramifications of global change that include, "an inequitable distribution and consumption of energy and other services, social breakdown, increased violence and a rise in new forms of social aggression, drug trafficking, growing drug use by young people, and the loss of identity" (LS 46). Chapter One of Laudato Si is Francis's list of the many destructive forces stripping bare the feast of our common home. These include pollution and climate change, the abuse of fresh water and its distribution, the loss of biodiversity, the decline in the quality of human life and the breakdown of society, global inequality, and weak responses on the part of international political leaders for any change. The cycle of decline famishes humanity from the awe-filled feast of truth, unity, goodness, and beauty. ${ }^{14}$

Therefore, an ecological conversion is a call for a radical communal change from the course of direction in which our common home is drastically falling so as to come back to the feast. Francis admits that "Christians have not always appropriated and developed the spiritual treasures bestowed by God upon the Church," and so he explains how conversion prefigures a time when "the life of the spirit is not dissociated from the body or from nature or from worldly realities, but lived in and with them, in communion with all that surrounds us" ( $L S \# 216)$. To partake in the feast of the embodiment of the Holy Spirit requires a grace-induced expansion of consciousness to see God's love present in creation and then to engage in the stewardship of this divine gift. Ecological conversion does align with Lonergan's conversion process, which Lonergan explained

\footnotetext{
${ }^{14}$ See Thomas Dubay, S.M., The Evidential Power of Beauty: Science and Theology Meet (San Francisco: Ignatius Press, 1999), 82-111.
} 
“occurs only inasmuch as a [person] discovers what is unauthentic in [one's self] and turns away from it, inasmuch as [this person] discovers what the fulness of human authenticity can be and embraces it with [the] whole [of one's] being." 15 An ecological conversion necessarily consists of purging, at both the individual and communal levels, the blinding, deafening, and numbing biases that are the sources of spiritual and physical starvation. ${ }^{16}$ Then, freed from bias and in agreement with Lonergan's conversion process of authentic self-appropriation, an ecological conversion consists of a two-fold movement of, first, humanity creatively and collectively reaching up to God in prayer and through meaningful labors of stewardship, and second, God laboring in and through all of creation by pouring forth healing grace from above into creation. ${ }^{17}$ Francis's call for ecological conversion harmonizes with and advances Lonergan's two-fold movement of conversion in that Francis teaches that the Eucharist is the font of the transformative creating, healing, and flourishing of all of creation. Of this great feast he writes, "The Eucharist joins heaven and earth; it embraces and penetrates all creation. The world which came forth from God's hands returns to him in blessed and undivided adoration: in the bread of the Eucharist, 'creation is projected towards divinization, towards the holy wedding feast, towards unification with the Creator himself"' ( $L S \# 236)$. For the sake of the life of the world, let us come to the feast!

\section{Bibliography}

Doran, Robert M. Theology and the Dialectics of History. Toronto, University of Toronto Press, 1990.

\footnotetext{
15 Lonergan, Method in Theology, 271.

16 This process of change is not easy and may take a long time. See Bernard J.F. Lonergan, "Healing and Creating in History" in A Third Collection, eds. Robert Doran and John Dadosky (Toronto: University of Toronto Press, 2017), 94-103.

${ }^{17}$ See St. Ignatius of Loyola, The Spiritual Exercises, trans. Louis J. Puhl (Chicago, IL: Loyola Press, 1951), \#236: "This is to consider how God works and labors for me in all creatures upon the face of the earth, that is, He conducts Himself as one who labors. Thus, in the heavens, the elements, the plants, the fruits, the cattle, etc., He gives being, conserves them, confers life and sensation, etc."
} 
The Trinity in History: A Theology of the Divine Missions: Volume Two: Missions, Relations, and Persons. Toronto: University of Toronto Press, 2019.

Dubay, Thomas. The Evidential Power of Beauty: Science and Theology Meet. San Francisco: Ignatius Press, 1999.

Francis, Pope. Laudato Si: Encyclical Letter of the Holy Father Francis On Care for our Common Home. https://www.vatican.va/content/francesco/en/encyclicals/documents/papafrancesco_20150524_enciclica-laudato-si.html, May 24, 2015.

Griffin, Emilie. Turning: Reflections on the Experience of Conversion. New York: Doubleday, 1980.

Ignatius of Loyola, Saint. The Spiritual Exercises. Translated by Louis J. Puhl. Chicago, IL: Loyola Press, 1951.

John Paul II, Pope. Centesimus Annus: Encyclical Letter of His Holiness Pope John Paul II on the Hundredth Anniversary of Rerum Novarum. https://www.vatican.va/content/johnpaul-ii/en/encyclicals/documents/hf_jp-ii_enc_01051991_centesimus-annus.html, May 1, 1991.

II on the Eucharist in its Relationship to the Church.

https://www.vatican.va/content/john-paul-ii/en/encyclicals/documents/hf_jp-

ii_enc_20030417_eccl-de-euch.html, April 17, 2003.

--------------. General Audience, Wednesday, January 17, 2001.

https://www.vatican.va/content/john-paul-ii/en/audiences/2001/documents/hf_jpii aud 20010117.html.

Man and Woman He Created Them: A Theology of the Body. Translated by Michael Waldstein. Boston: Pauline Books and Media, 2006.

Lonergan, Bernard J.F. “Analysis of Faith.” Method: Journal of Lonergan Studies 20, no. 2 (2002), 125-154.

. "Grace and the Spiritual Exercises of St. Ignatius." Method: Journal of Lonergan Studies, 21, no. 2 (2003), 90-91.

- Insight: A Study of Human Understanding, Collected Works of Bernard Lonergan, Volume 3. Edited by Frederick E. Crowe and Robert M. Doran. Toronto: University of Toronto Press, 2000.

Method in Theology. Toronto: University of Toronto Press, 1990. 
"Natural Knowledge of God." In A Second Collection: Collected Works of Bernard Lonergan, Volume 13. Edited by Robert M. Doran, S.J. and John Dadosky. Toronto: University of Toronto Press, 2016.

--------------. “Theology in its New Context.” In Renewal of Religious Thought: Proceedings of the Congress on the Theology of the Renewal of the Church Centenary of Canada, 1867-1967. Edited by L.K. Shook, C.S.B.. Montreal: Palm Publishers, 1986.

---------------. "Healing and Creating in History." In A Third Collection, Collected Works of Bernard Lonergan, Volume 16. Edited by Robert M. Doran, S.J. and John Dadosky. Toronto: University of Toronto Press, 2017.

Wojtyla, Karol. Love and Responsibility. Translated by H.T. Willetts. New York: Farrar, Straus, Giroux, 1981. 